\section{Un judío con muchos rostros: exégesis y teología en Filón de Alejandría*}

\author{
Juan Sebastián Hernández-Valencia ${ }^{a}$ \\ Universidad Pontificia Bolivariana, Colombia \\ https://orcid.org/0000-0002-9567-4205
}

RECIBIDO: 20-09-18. APROBADO: 15-05-19

Resumen: La obra y figura teológica de Filón de Alejandría ha estado abierta a múltiples interpretaciones durante el siglo XX y lo corrido del XXI. ¿Cómo entenderlas? ¿Como relectura de la tradición de la Biblia a la luz del platonismo medio, o como apología sobre el valor cultural del judaísmo ante la paideia griega? En el artículo se aborda este problema a partir de la correlación entre exégesis y teología en la obra de Filón. Este, como exégeta comenta la Torah. Su método de exégesis no es el midrash o el pesher, sino la alegoresis, propia de la tradición estoica. Como teólogo, Filón propone un sistema notable, desechado por la naciente corriente farisaico-rabínica. En el artículo se exploran dos líneas de la amplísima teología filónica. La primera expone a la teología mística como centro de su sistema teológico. La segunda trata el problema de la teodicea.

Palabras clave: Filón de Alejandría; teología; judaísmo helenístico; exégesis.

\section{A Jew with Many Faces: Exegesis and Theology in Philo of Alexandria}

Aвstract: The work and theological figure of Philo of Alexandria has been open to multiple interpretations during the $20^{\text {th }}$ Century and the run of the $21^{\text {st }}$. How to understand them? As a rereading of the tradition of the Bible in light of Middle Platonism, or as an apology on the cultural value of Judaism before the Greek paideia? This problem is approached in this article with the perspective of the correlation between exegesis and theology in the work of Philo. As an exegete, Philo comments on the Torah. His method of exegesis is not the midrash or the pesher, but rather the alegoresis, typical of the Stoic tradition. As a theologian, Philo proposes a remarkable system, discarded by the nascent Pharisaicrabbinical current. In this article, two lines of the very wide philonic theology are explored. The former exposes mystical theology as the center of its theological system. The latter deals with the problem of theodicy.

Key Words: Philo of Alexandria; Theology, Hellenistic Judaism; exegesis.

\section{Cómo CITAR: \\ Hernández-Valencia, Juan Sebastián. "Un judío con muchos rostros: exégesis y teología en Filón de Alejandría". Theo- logica Xaveriana (2020): 1-25. https:// doi.org/10.11144/javeriana.tx70.jretfa}

\footnotetext{
*Artículo de reflexión






\section{Problemas y perspectivas de los estudios filónicos}

Es indiscutible la masiva y profunda influencia de la cultura helenística en el judaísmo del segundo Templo. Y no solo en la diáspora, como Alejandría o Antioquia, sino también en Palestina, como lo señala Hengel. No obstante, la comunidad judía de Alejandría es el mejor ejemplo del judaísmo helenizado: en textos como Sabiduría, la Carta a Aristeas o los Oráculos sibilinos, y en la traducción de los LXX se nota el temple literario-exegético del judaísmo alejandrino, con sus ampliaciones y comentarios de tipo midrásico y otras veces alegórico-estoico en función de una apología del judaísmo².

En autores como Demetrio, Aristóbulo -el así llamado "primer filósofo judío"Filón el Poeta y Artapano se expresa mejor el talante apologético y midrásico de la escuela judía alejandrina ${ }^{3}$. No obstante, pocos autores reúnen y expresan la gestalt del judaísmo helenista mejor que Filón de Alejandría.

El interés que él ha despertado entre los estudiosos cristianos ha sido grande. Sin embargo, no existe una imagen unificada sobre su figura, que se presenta con sus dos características más llamativas: su teología y exégesis. Los investigadores lo presentan de varias formas ${ }^{4}$. Wolfson lo ha visto como un fariseo, constructor de un gran sistema

\footnotetext{
${ }^{1}$ Hengel, Giudaismo ed ellenismo; Hengel, The Hellenization of Judaea in the First Century after Christ. Para una visión más amplia de las diferentes aproximaciones ofrecidas en los estudios filónicos, de las cuales solo se da un dossier minimum en el presente planteamiento del problema, véase a Winston, Logos and Mystical Theology in Philo of Alexandria; Calabi, God's Acting, Man's Acting; Calabi (ed.), Italian Studies on Philo of Alexandria; Runia, Philo of Alexandria. On the Creation of the Cosmos According to Moses; Runia, Philo in Early Christian Literature; Runia, Exegesis and Philosophy; Runia, Philo of Alexandria and the Timaeus of Plato, Vol. 1.
}

${ }^{2}$ Véase a Reventlow, History of Biblical Interpretation. Volume 1: From the Old Testament to Origen, 19-26 (para los LXX); y 40-46 (para Filón).

${ }^{3}$ De las obras de estos autores judíos helenistas solo nos han llegado fragmentos. No obstante, en ellos se pueden ver su idiosincrasia cultural y religiosa. Plenamente judíos, hablan y piensan en categorías y conceptos helenísticos, abogando por la primacía y la superioridad de la Torah. Frecuentemente presentan a Moisés como prototipo de los filósofos y poetas griegos. Sobre esto véase a Grabbe, $A$ History of the Jews and Judaism in the Second Temple Period. Vol. 2: The Early Hellenistic Period, 335-175 BCE; Grabbe (ed.), Did Moses Speak Attic? Jewish Historiography and Scripture in the Hellenistic Period; Hengel, Giudaismo ed ellenismo, 519-543; Holladay, Fragments from Hellenistic Jewish. Vol. 3: Aristobulus; y Stone, Jewish Writings of the Second Temple Period.

${ }^{4}$ Sobre el tema existe una extensa bibliografía. Sin pretender realizar una exposición minuciosa, y menos completa sobre el tema, se presenta la lista de autores que ofrecen buenas introducciones y estudios bibliográficos: Runia y otros, "Philo of Alexandria: An Annotated Bibliography (2014)", 185-228; Runia y Radice, Philo of Alexandria: An Annotated Bibliography. 1997-2006; Runia y Radice, Philo of Alexandria: An Annotated Bibliography. 1987-1996; Runia y Radice, Philo of Alexandria: An Annotated Bibliography. 1937-1986. Cubre las obras (colecciones, monografías, artículos) aparecidas entre los años 1937 a 2006 en diferentes idiomas: inglés, francés, español, alemán, sueco, holandés, italiano, entre otros. El estudio bibliográfico de Goodhart, y Goodenough, "A General Bibliography of Philo Judaeus”, 125-321, cubre 
filosófico 5 Para Dillon, Filón es un judío completamente helenizado, representante del platonismo medio ${ }^{6}$. El gran investigador Erwin Ramsdell Goodenough influyó notablemente los estudios filónicos del siglo XX con su presentación de Filón como un místico judío ${ }^{7}$. En esta misma línea mística, otros investigadores ven en Filón a un representante del gnosticismo ${ }^{8}$, e incluso del misticismo platónico?.

La existencia de tan amplia y diversa perspectiva académica sobre Filón obedece a que, en sus escritos, se mezclan diferentes elementos del platonismo medio con nociones bíblicas. Ellos parecen reflejar la presencia de diferentes tradiciones en el judaísmo alejandrino. Así mismo, el énfasis que Filón hace sobre la ascensión celestial y la etimología de Israel entendida como "aquel que ve a Dios" y, por tanto, en contacto con las visiones celestiales, ya sugerían -para Birnbaum y Scholem- que aquel tenía conocimiento de las primitivas tradiciones místicas judías, cercanas a la merkabah ${ }^{10}$.

La vasta producción de Filón, así como los métodos y los medios exegéticos empleados en ella, sugieren la presencia de una escuela, una especie de beth-midrash, aunque -como advierte Loveday- la escasa presencia de argumentos y evidencias en las fuentes deja abierta la ventana a la imaginación de los académicos ${ }^{11}$. ¿Fue Filón quién fundó dicha escuela? ¿O la recibió, o hace parte de una escuela sinagogal?²

no solo la literatura antigua, también los manuscritos: griegos, latinos y armenios, y las ediciones y traducciones a la obra filónica: griego, armenio, latín, holandés, inglés, francés, alemán, hebreo, húngaro, italiano, ruso, español (solo una traducción de 1789) y sueco. David T. Runia y el equipo del seminario de estudios filónicos presentan cada dos años una actualización bibliográfica en el número correspondiente de Studia Philonica Annual: Studies in Hellenistic Judaism. La última actualización se presentó en 2017, y se puede consultar en línea: https://www.sbl-site.org/publications/ICI Studia Philonica.aspx

${ }^{5}$ Wolfson, Philo: Foundations of Religious Philosophy in Judaism, Christianity and Islam, Vol. 1: Structure and Growth of Philosophical Systems from Plato to Spinoza.

${ }^{6}$ Dillon, The Golden Chain: Studies in the Development of Platonism and Christianity, 1-8.

${ }^{7}$ Goodenough, An Introduction to Philo Judaus, 178-218; Goodenough, "New Light on Hellenistic Judaism", 18-28.

${ }^{8}$ Jonas, Gnosis und spätantiker Geist. Bd. 1: Die mythologischer Gnosis; Pearson, "Christians and Jews in First-Century Alexandria", 207-209; y Klein, Die Lichtterminologie bei Philon von Alexandrien und in den hermetischen Schriften.

${ }^{9}$ Alekniené, "L'extase" mystique dans la tradition platonicienne: Philon d'Alexandrie et Plotin", 53-82.

${ }^{10}$ Birnbaum, The Place of Judaism in Philo's Thought, 76; y Scholem, Jewish Gnosticism, Merkabah Mysticism, and Talmudic Tradition, 60.

${ }^{11}$ Loveday, "Schools, Hellenistic”, 1005-1111.

${ }^{12} \mathrm{Si}$ bien, Sterling defiende la idea de ver tras los escritos filónicos una escuela filosófica privada, no desecha la posibilidad de identificar tal estructura social en la sinagoga de Alejadría (Sterling, "'The School of Sacred Laws': The Social Setting of Philo's Treatises", 148-164). De hecho, el mismo Filón usa cierto vocabulario que parece referir tal identificación. Por ejemplo, en Leg 311-312, Filón describe las sinagogas

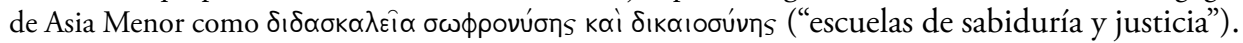


Bousset defendió la existencia de una escuela judía de exégesis alegórica ${ }^{13}$ mientras Wolfson y Culpepper señalaron la existencia de una escuela sinagogal de educación superior ${ }^{14}$. La sugerencia de Wolfson ha sido aceptada, con modificaciones, por Nikiprowetzky, quien habla de unas "escuelas de sabios" (écoles de sagesse) ${ }^{15}$; también por Sterling, quien sostiene que Filón fundó una escuela exegética en su propia casa ${ }^{16}$; y por Cohen, quien afirma que Filón era parte de un círculo de estudios (haftarah) que buscaba alegorizar la Biblia hebrea de acuerdo con las escuelas filosóficas helenísticas ${ }^{17}$.

Como ya se anotaba, la causa de tanta discrepancia concurre con el lugar donde se debe buscar su solución: el extenso opus filoniano y su método exegético. El presente estudio busca indagar sobre el método exegético filónico y el surgimiento de su teología a partir de dicho método.

Sin embargo, la obra de Filón no se produce ex nihilo, ni "cae del cielo" de forma meteórica; mejor, se origina en un contexto cultural: el encuentro entre la literatura judía con la griega; pero antes de abordar algún análisis de la obra y método exegético de Filón conviene decir algo, aunque breve, sobre dicho contexto cultural.

\section{Alejandría y el judaísmo helenizado}

Después de su fundación por Alejandro Magno en el 332 a. C., y bajo el patronazgo cultural de los Ptolomeos, Alejandría se constituyó en la Atenas de Oriente. Reconocida en todo el Mediterráneo helenístico por el Mouseion y la Librería real, dos de los emblemas institucionales de la cultura helenista, Alejandría se convirtió en cuna de filósofos e intelectuales desde los tiempos de Ptolomeo I, Sotér, en el siglo III a. C. ${ }^{18}$. En esta ciudad maduró, como en ningún otro lugar, el sueño de Alejandro Magno:

\footnotetext{
${ }^{13}$ Bousset, Jüdisch-christlicher Schulbetrieb in Alexandria und Rom.

${ }^{14}$ Wolfson, Philo: Foundations of Religious Philosophy in Judaism, Christianity and Islam. Vol. 1: Structure and Growth of Philosophical Systems from Plato to Spinoza; y Culpepper, The Johannine School, 197-204.

${ }^{15}$ Véase como ejemplo de la recepción crítica que Nikiprowetzky, Le commentaire de l Écriture chez Philon ¿Alexandrie, hace de las ideas de Wolfson, la siguiente argumentación: "Quant à l'idée de Wolfson qui veut que dans les 'écoles de sagesse’ aient été occupées à des études de caractère universitaire et profane, elle repose assurément sur un contresens. Il n'en est pas moins vrai que l'origine des traités exégétiques de Philon doit bien être cherchée à la synagogue" (Wolfson, Philo: Foundations of Religious Philosophy in Judaism, Christianity and Islam. Vol. 1: Structure and Growth of Philosophical Systems from Plato to Spinoza; 5).

${ }^{16}$ Sterling, “The School of Sacred Laws': The Social Setting of Philo's Treatises”, 148-164. Este autor apoya su intuición en los informes dados por el obispo de Helwan, del siglo VI, Barhadbsabba 'Arbaya, quien señalaba a Filón como el fundador de la escuela de Alejandría.

${ }^{17}$ Cohen, Philo's Scriptures Citations from Prophets and Writtings.

${ }^{18}$ Sobre esto, véase a Watts, City and School in Late Antique Athens and Alexandria.
} 
la sincresis entre la cultura griega y los valores culturales orientales, la gran ómóvoı́, o la "unión de los corazones"19.

El concepto de homonoia -literalmente [tener] una mentalidad en común o, según la traducción de Tarn, union of heart $3^{20}$, que en latín es traducido como concordiafue empleado por Isócrates para justificar el proyecto político de Filipo de Macedonia, padre de Alejandro, con el cual pretendía conseguir la unidad y aceptación de los griegos. No obstante, la xenofobia griega impedía considerar a los bárbaros como pares. Al parecer, Isócrates es el primer escritor que difunde la idea de una ónóvoı $\alpha$ entre griegos y bárbaros. En sí, la ómóvoı́ se fundaba en la idea del gobierno supremo y universal del rey griego, quien debía procurar la unidad e igualdad entre los griegos.

En Alejandría se produce otra gran sincresis: la unión de las epistemologías y las teologías, es decir, cosmología, psicología y ontología, de las escuelas platónicas, aristotélicas y estoicas. En otras palabras: Alejandría es la cuna del así llamado platonismo medio ${ }^{21}$. Además de los académicos, los peripatéticos y los estoicos, Alejandría llamó la atención de la comunidad judía que pronto se organizó en la ciudad, como un políteuma ${ }^{22}$.

En este medio social y cultural se observa el crecimiento de la interacción entre la cultura helenística alejandrina y la comunidad judía, así como el desarrollo de la teología helenísta judía, teología que se desarrolla de forma privilegiada en los escritos de Filón de Alejandría.

${ }^{19}$ Sobre esto, y lo que se dice en el párrafo siguiente, véase a Tarn, Alexander the Great. Volumen 2: Sources and Studies, 409-417.

${ }^{20}$ Ibid., 400.

${ }^{21}$ Por platonismo medio (como lo llama Praechter) o, más sencillamente, nueva academia (como lo llama Krämer) se entiende el desarrollo de la Academia comprendida entre Antíoco de Ascalón (ca. 130-68 a. C.) y Plotino (204-270 d. C.): caracterizado por el rechazo del escepticismo, por la dogmatización de los principios de la metafísica platónica, y por la sincresis con la ética estoica y aristotélica. Desde Eudoro de Alejandría (siglo I a. C.), la metafísica trascendental prevaleció, con su presentación del dios supremo o mónada, el segundo dios, creador, y el alma del mundo. Con esta metafísica escalonada, se presentó un cambió en la ética substituyendo el té̉os y la similitudo dei platónica, por la doctrina de la "asimilación a la naturaleza", formulada por Antíoco. Además de las ya nombradas, las figuras más representativas del platonismo medio son: Plutarco, Albino, Apuleyo, Nicómaco de Gerasa y Numenio. Filón de Alejandría es un buen ejemplo del platonismo medio en su fase inicial. Luego de agotarse la chispa platónica con el repertorio metafísico del platonismo medio, en la escuela de Alejandría se desarrollará el neoplatonismo, con Proclo, Hermeia y Amonio. La expresión platonismo medio fue implementada por Karl Praechter a principios del siglo XX, en su estudio sobre la filosofía antigua. Sobre esto, véase a Praechter, Friedrich Ueberwegs. Grundrifs der Geschichte der Philosophie. Erster Teil: Das Altertum, 536-537; y Krämer, Platonismus und hellenistische Philosophie, 5-13

${ }^{22}$ Los políteumas, eran unidades territoriales con jurisdicción autónoma; usualmente el criterio de conformación de los políteumas era étnico. La característica que hacía al políteuma judío uno suis generis es la configuración jurídica a partir de la Torah. Sobre esto, además de Vílchez, Sabiduría, 491-494, véase a Manning, Land and Power in Ptolemaic Egypt. 


\section{Los escritos y el método exegético de Filón ${ }^{23}$}

Estos se suelen dividir en dos grupos: (1) Exposiciones sobre la $\operatorname{Torah}^{24}$ y (2) comentarios exegéticos ${ }^{25}$. El primer grupo pertenece a un proyecto mayor, inconcluso, que habría de dividirse en tres grandes partes: la historia de la creación, la parte histórica y la legislativa, que buscaba reescribir la Torah a manera de comentario, la cual en su estado actual abarca Gn 2-41. Filón emplea métodos tanto judíos como griegos en su producción exegética.

Por un lado, el método aplicado a sus exposiciones es el de expansión y paráfrasis del texto bíblico, similar al encontrado en el Libro de los Jubileos, el Génesis Apocryphon (1Q20, ó 1QApGn) y Las antigüedades bíblicas del Pseudo-Filón. Cabe señalar que los comentarios filónicos, al ser más cercanos a los midrashim palestinenses que al estilo de los comentarios qumrámicos (pesherim) permiten constatar la cercanía de Filón a los métodos exegéticos palestinenses ${ }^{26}$.

Por otro lado, los comentarios filónicos también siguen el método de cuestiónrespuesta, que pertenece al estilo de los comentarios helenistas efectuados sobre la obra de Homero. Estos presentan dos niveles de interpretación: el literal y el alegórico. De forma curiosa, como también lo ha señalado Saudelli, Filón no subraya más la importancia de la alegoría sobre la interpretación literal, sino que parece emplearlos en un estado de equilibrio ${ }^{27}$. Sobre su método exegético, el mismo Filón dice:

\footnotetext{
${ }^{23}$ Sobre el método exegético en la construcción de la obra de Filón, seguimos a Borgen, Philo of Alexandria: An Exegete for His Time; Borgen, "Philo of Alexandria", 333-342; y Moreau, "A Noocentric Exegesis: The Function of Allegory in Philo of Alexandria and Its Hermeneutical Implications", 61-80. Así mismo, Seguimos la nomenclatura filónica de Colson, Whitaker y Marcus (trads. y eds.), Philo Judaeus I, xxiii-xxiv. Además de las obras que se enumeran, están otras dos, de carácter diplomático y biográfico: De Legatione ad Gaium (Leg), In Flaccum (Flacc). Finalmente, existen fragmentos de los siguientes dos tratados: Hypothetica, Apologia pro Iudaeis (Hyp), y De Providentia (Prov).

${ }^{24}$ En aras de la claridad expositiva, se presentan las obras filónicas que se incluyen bajo esta categoría: De opificio mundi (Opif), De Abrahamo (Abr), De Josepho (Jos), De vita Mosis I-II (Mos I-II), De decalogo (Decal), De specialibus legibus I-IV (Spec), De virtutibus (Virt), De praemiis et poenis (Praem), De vita contemplativa (Cont), De aeternitate mundi (Aet).

${ }^{25}$ Siguiendo con el propósito de ofrecer una exposición clara y completa, se presentan las obras filónicas que se incluyen bajo esta categoría: Legum allegoriarum I-III (Leg. I-III), De Cherubim (Cher), De sacraficiis Abelis et Caini (Sac), Qoud deterius potiori insidiari soleat (Det), De posteritati Caini (Post), De gigantibus (Gig), Qoud Deus sit immutabillis (Deus), De agricultura (Agr), De plantatione (Plant), De ebrietate (Ebr), De sobrietate (Sob), De confusione linguarum (Conf), De migratione abrahami (Mig), Quis rerum divinarum heres sit (Heres), De congressu quaerendae eruditionis gratia (Cong), De fuga et inventione (Fug), De mutatione nominum (Mut), De somnis (Som).

${ }^{26}$ Sobre esto, véase a Díez Macho, Apócrifos del Antiguo Testamento. Tomo 1: Introducción general, 181-182, 187-188; y a Aranda Pérez y otros, Literatura judía intertestamentaria, 128-131.

${ }^{27}$ Saudelli, “Loi de Moïse et philosophie grecque: le judaïsme alexandrin”, 726-731.
} 


\section{Mig 89}

Existen algunos que, puesto que entienden las leyes literales (oí toùs ṕntoùs vónous) como símbolos de hechos inteligibles, muestran respecto de estos un rigor excesivo, pero a las primeras las subestiman tomándolas a la ligera. Podría censurarlos por su habilidad de manos, ya que sería necesario que cuidaran de ambos aspectos, la investigación de los significados más completa y exacta del

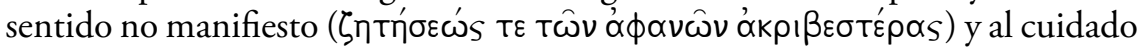

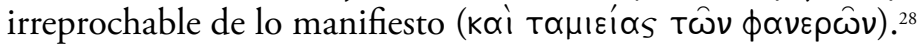

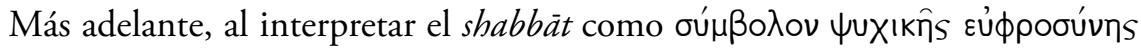
("símbolo de la felicidad del alma") y del agradecimiento a Dios, así como la enseñanza moral que encierra la institución de la circuncisión, Filón invita a no olvidar la importancia de la comprensión literal de estos dos ritos:

$\operatorname{Mig} 92$

Ya que si solo nos atenemos a mostrar el significado interior de las cosas

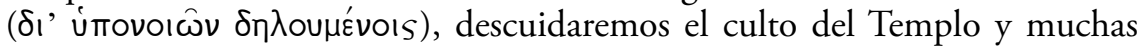
otras cosas. ${ }^{29}$

A continuación explica:

\section{Mig 93}

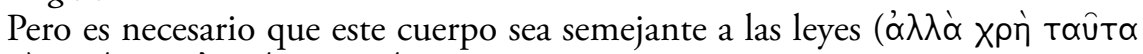

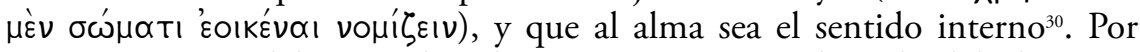
tanto, como se debe atender al cuerpo, porque es la sede del alma, así

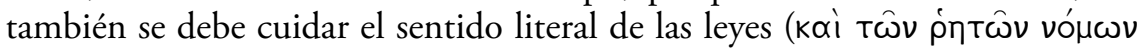
$\left.\varepsilon \pi ı \mu \varepsilon \lambda \eta T \varepsilon^{\prime} \circ v\right)$ porque, observándolas, se tendrá un conocimiento más claro de aquellas realidades de las que son símbolos, y se evitarán las censuras y las críticas de la muchedumbre. ${ }^{31}$

${ }^{28}$ Colson, Whitaker y Marcus (trads. y eds.), Philo Judaeus IV, 182. Véase también a Martín (dir.), Filón de Alejandría. Obras completas III, 103-104. En lo sucesivo se sigue el texto griego de Colson, así como las traducciones castellanas ofrecida por Martín (dir.) y Triviño (trad.), tituladas Filón de Alejandría. Obras completas, con algunas modificaciones propias cuando se necesite una traducción más literal para aclarar aspectos de su interpretación.

${ }^{29}$ Colson, Whitaker y Marcus (trads. y eds.), Philo Judaeus IV, 184; Martín (dir.), Filón de Alejandría. Obras completas III, 104.

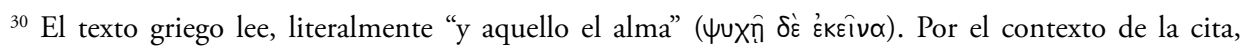
el lector puede entender perfectamente que Filón se refiere, en su analogía, al sentido interno de la Ley. Por eso Martín (dir.), Filón de Alejandría. Obras completas III, 104, pueden traducir el inicio de la cita así: "Al contrario, es necesario creer que estos aspectos se refieren al cuerpo y al alma, respectivamente".

${ }^{31}$ Colson, Whitaker y Marcus (trads. y eds.), Philo Judaeus IV, 184; Martín (dir.), Filón de Alejandría. Obras completas III, 104-105. 
En estos pasajes Filón expone su talante exegético. Aunque tiene por superior al nivel alegórico, que denomina como "significado interior" (úróvol $\alpha)^{32}$ y "no-manifiesto" (’’фavepós), no considera que este invalide o anule el nivel literal, llamado "lo concreto, preciso" (ṕntós), "lo manifiesto, evidente, conocido" (фavepós), y "lo evidente" ( $\delta \hat{\lambda} \lambda \circ \varsigma)$. Filón combina ambos niveles; sin despreciar la exposición literalista, la une con la interpretación alegorista, buscando lo que él llama una inves-

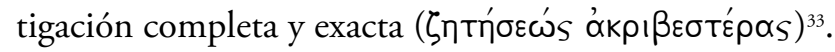

La discusión sobre la fuente o fuentes que Filón utiliza para su exégesis sigue abierta al debate. Se ha llegado a afirmar que este se resolvería hablando de dos Filones: uno de Alejandría y otro palestinense ${ }^{34}$. ¿ Se debe buscar su fuente en el método alegórico empleado por los estoicos para leer los fenómenos naturales y la ética en Homero ${ }^{35}{ }_{¿} \mathrm{O}$ en el método de la hagadá palestinense, en la cual se idealiza a los patriarcas bíblicos por medio de etimologías? ${ }^{26}$ ¿O incluso en el método alegórico empleado por la escuela sinagogal alejandrina, compartido con otros exponentes de dicha escuela como Aristóbulo?37

32 El vocablo griego úróvoı significa, literalmente: "por debajo del entendimiento"; se deriva del

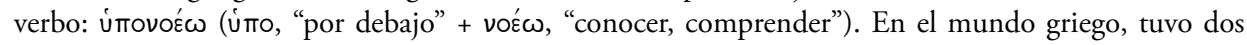
significados: "suponer, sospechar", y "significado real que yace en el fondo del asunto o cosa tratada". Este segundo uso es el encontrado en autores como Platón (Rep., 378d) y Aristóteles (Eth. nic., 1, 128a24). El primero se encuentra en literatura religiosa como la Biblia griega. Véase a Liddell y Scott, A Greek-English Lexicon, 1890. Filón se aparta del significado que los LXX y el Nuevo Testamento le dan al vocablo úróvoı. Éste, aparece 3 veces en la LXX, con el sentido de "especulación, suposición" (Sir 3,24; Dn 4,16; 5,6). En el Nuevo Testamento tanto el sustantivo úróvoı́ como el verbo

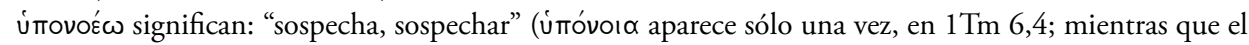
verbo úmovoź $\omega$ aparece 3 veces en Hch: 13,25; 25,18; 27,27). Sobre estas estadísticas, véase a Aland, Vollständige Konkordanz zum Griechischen zum Neuen Testament, 286-287. Según explica Cadiou (Philon D'Alexandrie: La Migration d Abraham, 49, Nota 2), Filón toma el vocablo del lenguaje profano, con la cual se designaba a las explicaciones realizadas en las alegorías molares y filosóficas. Pero Moulton ya informaba que el significado básico que tenían estos vocablos en la cultura general de la época era el de "sospecha", según lo atestiguan los papiros griegos de la época. En este sentido, con el uso que Filón le daba al vocablo úmóvoı a se alejaba no sólo de la LXX, de los autores neotestamentarios, sino también del uso popular; acercándose al que le daban los filósofos. Sobre esto, véase a Moulton, The Vocabulary of the Greek Testament Illustrated from the Papyri and Other Non-Literary Sources, 659; y también a Muraoka, A Greek English-Lexicon of the Septuagint, 705.

${ }_{33}$ Beumer, El Método Teológico, 8, también sostiene que la alegoresis filónica es un verdadero método teológico.

${ }^{34}$ Brewer, Techniques and Assumptions in Jewish Exegesis Before 70 CE., 201-204.

${ }^{35}$ Así lo supone Anderson, "allègoria", 16. En contra está Brewer, Techniques and Assumptions in Jewish Exegesis Before 70 CE., 200.

${ }^{36}$ Así lo cree Borgen, Philo of Alexandria: An Exegete for His Time.

${ }^{37}$ Sobre esto, véase a Niehoff, Jewish Exegesis and Homeric Scholarship in Alexandria; Matusova, "Allegorical Interpretation of the Pentateuch in Alexandria: Inscribing Aristobulus and Philo in a Wider Literary Context", 1-52. 
Sin importar los interrogantes y las hipótesis surgidas respecto del método preciso de Filón, es innegable que en los estudios filónicos va creciendo la tendencia a entender los trabajos de Filón como obras exegéticas.

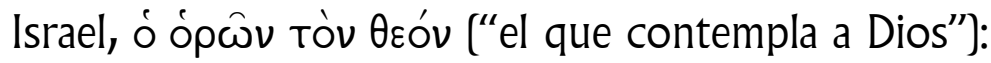 la teología filónica}

Su teología es la típica del misticismo: una teología negativa ${ }^{38}$. Filón sostiene que Dios es incognoscible y trascendente; es lo perfecto, lo bueno y lo bello; es tó ôv ("aquel que es, aquel que existe") y ó őv ("el existente"), pero que no se deja ver ${ }^{39}$. En esto, Filón sigue en la línea de la teología alejandrina (Si 35,17) $)^{40}$. En un pasaje de su obra, al comentar varios apartados del Exodo, Filón expone estas dos notas de su teología:

\section{Mut 7-11}

Sin embargo, no pienses que el que existe ( Tò őv), el que existe de verdad, es

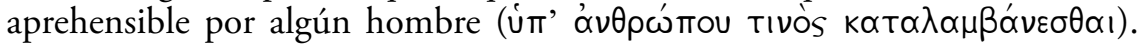
Porque no tenemos en nosotros mismos ningún órgano, por el que podamos

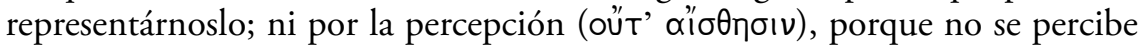
por los sentidos, ni por la inteligencia [...] El regalo más suficiente en sí mismo

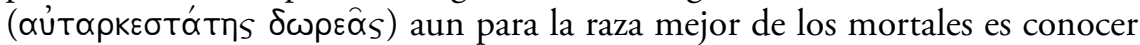
lo que está más allá del que existe, porque está dicho: "Verás lo que está detrás de mí; pero mi rostro no será visto por ti" (Ex 33,23), pues todo cuanto viene después del que existe, tanto los elementos corpóreos como los hechos inmateriales, llegan a percibirse, si bien no todos se perciben aún; pero él es el único que por naturaleza no puede ser visto. ¿Y qué tiene de asombroso que el que existe sea imperceptible a los hombres, cuando el intelecto que está en cada uno nos es desconocido? Porque ¿quién ha visto la esencia del alma? Cuya oscuridad ha suscitado miles de disputas entre los sofistas, que han aportado opiniones contrarias o incluso de géneros totalmente opuestos. Ciertamente era congruente que no pudiera ser asignado un nombre propio al que es en verdad. ¿¿No ves que al profeta que desea saber qué debe responder a quienes preguntan acerca de su nombre, Dios le dice que "yo soy el que soy $(\operatorname{Ex} 3,14)$, que es lo mismo que decir: "mi naturaleza es el ser, no el ser expresado"?

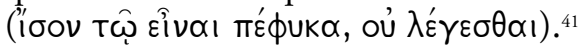

\footnotetext{
${ }^{38}$ Así Beumer, "El método teológico", 8.

${ }^{39}$ Sobre esto, véase a Winston, Logos and Mystical Theology in Philo of Alexandria.

${ }^{40}$ Sobre esto, véase a Nairne, The Alexandrine Gospel: Sirach, Wisdom, Philo, the Epistle to the Hebrews.

${ }^{41}$ Colson, Whitaker y Marcus (trads. y eds.), Philo Judaeus V, 144 y 146; Martín (dir.), Filón de Alejandria. Obras completas III, 365.
} 
El pasaje clave del texto anterior lo ofrecen los comentarios a Ex 3,14-15, donde Filón, a la par de ofrecer una teología negativa ${ }^{42}$, también afirma una línea teológica creacionista, similar a la de Pablo, en Rm 1,28 ${ }^{43}$. Es decir, Filón también sostiene una teología natural, en la cual habla sobre las actividades divinas, que él, más adelante

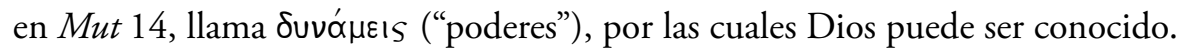

Mut 14

Así, ciertamente, el que existe es inefable, hasta el punto de que ni los poderes

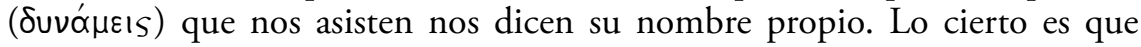
después de la lucha que el atleta ha librado para la adquisición de la virtud, dice al supervisor invisible: "Hazme saber tu nombre”; y él dice: "¿Para qué preguntas mi nombre?” (Gn 32,29), y no revela su particular nombre propio. Pues "te basta, dice, con sacar provecho siguiendo mis palabras de aliento, pero los símbolos de los seres creados, los nombres, no los busques en las naturalezas incorruptibles". ${ }^{44}$

En Opif 72 y 75, al comentar el plural de Gn 1,26 ("hagamos"), señala la acción

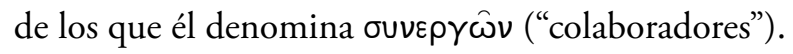

\section{Opif72}

No estaría desacertado si se plantease la pregunta de por qué razón se atribuye la creación del hombre no a un solo creador, como en el caso de las demás criaturas, sino a un mayor número, según parece desprenderse del texto. Presenta, efectivamente, al padre del universo expresándose de esta manera: "Hagamos al hombre según nuestra imagen y semejanza" (Gn 1,26). Por ventura, entonces, diría yo, aquel al que todas las cosas están sujetas, ¿̇tiene necesidad de otro alguno? Si cuando creaba el cielo, la tierra y el mar no tuvo necesidad de nadie que cooperara con él, ¿no habría de ser capaz, sin colaboradores

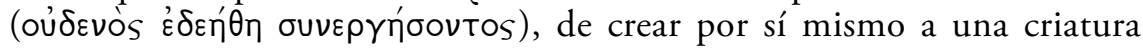
tan débil y perecedera como el hombre? La verdad plena sobre la causa de ello por fuerza solo Dios la sabe, pero la que parece por verosímil ser una conjetura digna de fe y razonable no hemos de omitir mencionarla. ${ }^{45}$

${ }^{42}$ Tal vez esta sea la línea de reflexión teológica más desarrollada en la teología cristiana posterior. Sin poder desarrollar más esta afirmación por la naturaleza del artículo y el límite en su extensión, se suscribe el comentario de Gilson (Las constantes filosóficas delser, 180-181): "Yahveh no consiente en definir, en expresar su esencia en una palabra [...] Santo Tomás no cesa en decirlo, quidditas Dei non est nobis nota, por consiguiente, es imposible formar una definición de ella".

${ }^{43}$ Sobre esto, véase a Wilckens, La Carta a los Romanos. Tomo 1: Rom 1-5, 143.

${ }^{44}$ Colson, Whitaker y Marcus (trads. y eds.), Philo Judaeus V, 148 y 150; Martín (dir.), Filón de Alejandría. Obras completas III, 366.

${ }^{45}$ Colson, Whitaker y Marcus (trads. y eds.), Philo Judaeus I, 56; Triviño (trad.), Filón de Alejandría. Obras completas I, 49. 


\section{Opif75}

Esta es la causa por la que solo en el caso de la creación del hombre Dios, según afirma Moisés, dijo "hagamos", plural que revela la participación conjunta

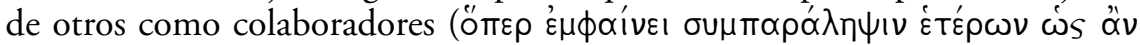
бuvep $\gamma \hat{\omega} v)$. El objeto fue que, cuando el hombre, obrara rectamente, con irreprochables designios y acciones, Dios, el soberano del universo, fuera reconocido como el origen de ellos; y en los casos contrarios la responsabilidad

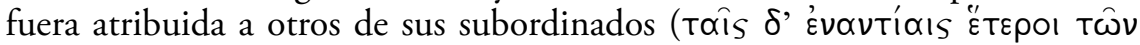
úтৃкó $\omega v$ ); ya que no es posible que el padre sea causa de mal para sus hijos; son un mal la maldad y las acciones viciosas. ${ }^{46}$

Como se puede notar, Filón soluciona el problema de la teodicea del judaísmo helenista por medio de estos poderes: ellos son los responsables de la maldad. En esto Filón presenta una versión paralela y diferente a la de la demonología henóquica ${ }^{47}$, aunque su solución se enfrenta con las concepciones rigoristas de la doctrina monoteísta rabínica posterior ${ }^{48}$. Filón también habla de otros poderes, subordinados a él; sin embargo, Dios no es responsable de sus acciones y efectos negativos. Más adelante, Filón resuelve la paradoja que presenta la subordinación de estos poderes a Dios, sin tener en él ninguna causa agente.

${ }^{46}$ Colson, Whitaker y Marcus (trads. y eds.), Philo Judaeus I, 58 y 60; Triviño (trad.), Filón de Alejandría. Obras completas I, 50.

${ }^{47}$ ¿Conocía Filón las tradiciones del Libro de los Vigilantes o el Libro de los Gigantes del Henoc etiópico o, en general, de la influencia de la "leyenda de la caída de los vigilantes" en otros textos del judaísmo del segundo templo? Stuckenbruck lo niega, aunque sostiene que la obra filónica De Gigantibus es un buen ejemplo de otra exegesis realizada sobre Gen 6,1-4. A pesar de lo que sugiere su nombre, el tratado De gigantibus de Filón es más una disertación platonizante de Gen 6,1-4 que una reflexión sobre los gigantes. Stroumsa sostiene que este tratado filónico desmitologiza la exégesis de Gen 6,1-4, mientras que 1 Hen 6-12 de hecho la remitologiza. Y Wright afirma que Filón conoce la tradición henóquica y polemiza contra su teodicea. Estas posiciones son debatibles, ya que en ninguna obra filónica existe una referencia ni un contacto directo y claro entre Filón y el Henoc etiópico. Sea como fuere, Filón no está interesado en elaborar una gigantología. De hecho, el tema central de este tratado se desarrolla al comentar Gen 6,3 (Gig. 19-57), donde discute la naturaleza del espíritu de Dios. En referencia al tema de los vigilantes y los gigantes, sólo dos aspectos llaman la atención de su tratado. (1) En Gig. 16 disgrega

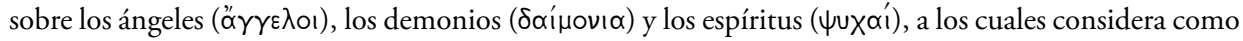

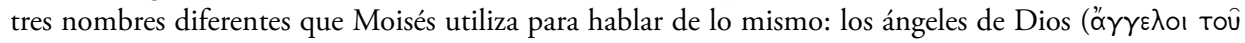
$\theta \varepsilon \circ \hat{)}$. (2) En Gig. 58-59, eleva una protesta respecto al tratamiento mítico de Gen 6,1-4. Sobre el texto de Filón, véase a Colson, Whitaker y Marcus (trads. y eds.), Philo Judaeus II, 446-479. Véase también a Stuckenbruck, The Book of Giants from Qumran, 39 (nota 145); Stroumsa, Another Seed: Studies in Gnostic Mythologies, 27-28; y Wright, The Origin of Evil Spirits: The Reception of Gen 6.1-4 in Early Jewish Literature, 205-219.

${ }^{48}$ Esta pudiera ser la razón que explica la escasa y casi nula influencia de la teología filónica en el judaísmo rabínico. Sobre el tema del dualismo modificado y las críticas rabínicas a las hipóstasis de Dios en el judaísmo helenista, véase a Segal, Two Powers in Heaven: Early Rabbinic Reports about Christianity and Gnosticism. 


\section{Conf 170-172}

Pues bien, en primer lugar, se debe afirmar que ninguno de los entes existe en el mismo rango de dignidad que Dios, sino que uno es el que gobierna, guía y es rey, al único que le es lícito presidir y administrar el universo. En efecto, el dicho: "No es un bien que manden muchos; uno sea el jefe, uno, el rey" (Ilíada 2, 204-205) podría, con justicia, aplicarse no tanto a las ciudades y los hombres cuanto mejor al cosmos y a Dios, porque uno solo es necesariamente el hacedor, padre y, a la vez, señor. De acuerdo con lo ya dicho, lo que ha de seguir será el desarrollo bien entramado de todo lo que se refiere a su naturaleza. Por tanto, examinemos de qué se trata. Dios es uno ( $\varepsilon \hat{i} s \omega ̋ v$ ó $\theta \varepsilon o ̀ s)$ pero tiene

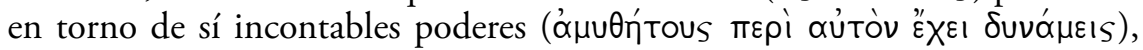

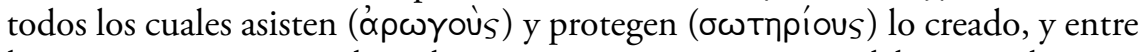
las que se cuentan también las que castigan; pero no se debe considerar su castigo para hacer dańo, sino que se trata de un castigo para evitar los pecados y corregirlos. Por medio de estos poderes se constituyó el mundo incorpóreo e inteligible, que es arquetipo de este mundo manifiesto, y que está compuesto de ideas invisibles como este de cuerpos visibles. ${ }^{49}$

Además de explicar la subordinación de estos poderes con efectos negativos como agentes de una instrumentalización moral, o como medios de corrección, la presencia de los conceptos de soberanía absoluta y de creación permite a Filón presentar en equilibrio otra paradoja teológica: la armonía entre la teología negativa y la natural ${ }^{50}$. Por la última, Filón se acerca más a la tradición del platonismo medio y del creacionismo bíblico; por la primera, Filón yace próximo al misticismo helenista.

No existe otro concepto que presente mejor esta paradójica armonía entre contrarios que el concepto derivado de la etimología filoniana del nombre Israel y la contemplación mística que implica. Al tiempo, este concepto es clave para comprender la antropología y la psicología filónica ${ }^{51}$. Para Filón, Israel significa "contemplar a Dios"

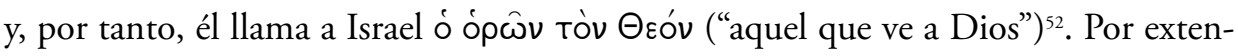
sión, el pueblo judío es denominado tò ópatıkòv Yévos ("la raza que contempla") s3,

\footnotetext{
${ }^{49}$ Colson, Whitaker y Marcus (trads. y eds.), Philo Judaeus IV, 102 y 104; Martín (dir.), Filón de Alejandría. Obras completas III, 67.

${ }^{50}$ Sobre la solución de esta contraditio viarorum, véase a Calabi, God's Acting, Man's Acting, 48-56, quien habla de la via negationes, via eminentiae y la via analogiae.

${ }^{51}$ Sobre esto, véase a Mackie, "Seeing God in Philo of Alexandria: the Logos, the Powers, or the Existent One?", 25-47.

${ }^{52}$ Entre otros pasajes, véase: $\operatorname{Leg} 2$ 2, 34; 3, 15, 172, 186, 212; Post 63, 89-92; Mig 113, 125; Con 51; Fug 208; Som 2, 44, 172-173.

${ }^{53}$ Véase los siguientes pasajes de Filón: Conf91-92; Mig 18, 54; Mut 109, 189, 258, Som 2, 279.
} 
o incluso, simplemente, ó ópatıkós ("el que contempla"), o oi ópatıkoí ("los que contemplan") $)^{54}$.

En su sentido teológico, por Israel, Filón siempre denota la mente o el alma humana. Algunas veces, Israel señala la mejor parte del alma: la parte intelectiva y

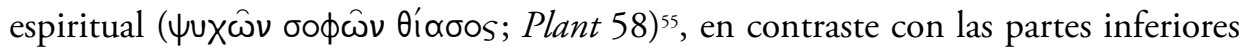
de la misma, por ejemplo, las afecciones, presentadas como las enemigas de Israel ${ }^{56}$. A veces, las divisiones en Israel, presentadas en la Ley, son explicadas como el conflicto entre los elementos del alma ${ }^{57}$.

Finalmente, llama la atención la unión de los problemas propios de la epistemología del platonismo medio, la teología natural y la negativa en el misticismo de

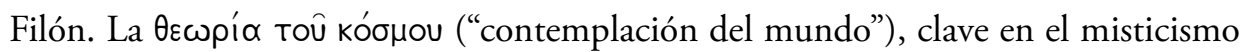
filónico, se presenta en el marco de una argumentación sobre la posibilidad de conocer a Dios, así como la clave para entender la paradójica armonía entre la teología negativa y la natural. Este aspecto contemplativo y místico del pensamiento de Filón ha llevado a cargar el acento sobre las posibles experiencias místicas que Filón parece relatar en sus escritos.

Spec 3,1-2

Hubo un tiempo, en que libre de otras ocupaciones, me entregaba al estudio

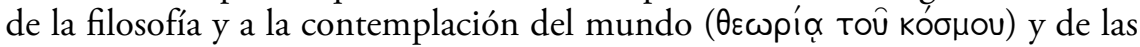
cosas que él contiene, y así recogía como fruto aquella vida hermosa, harto apetecible y verdaderamente feliz, acompańado siempre de divinos asuntos y doctrinas, con los que me sentía dichoso, sin que jamás me sobreviniera la hartura o la saciedad. Nada bajo o abyecto encerraban mis pensamientos, ni me retorcía en procura de fama, de riqueza o de los goces propios del cuerpo; antes bien, tenía la impresión de avanzar siempre por las alturas, poseída mi

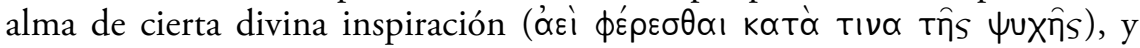
girar a la par del sol, la luna y la totalidad del cielo y el mundo. Y entonces sí que, inclinándome desde las etéreas alturas y dirigiendo, como desde una atalaya, la mirada de mi inteligencia contemplaba los infinitos espectáculos de

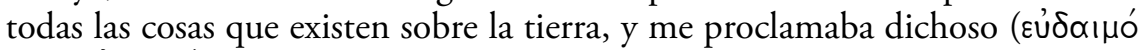

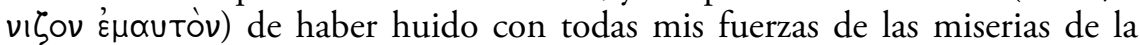
vida mortal..$^{58}$

\footnotetext{
${ }^{54}$ Véase los siguientes pasajes: Mig 163; Plant 46-47.

${ }^{55}$ Véase también: Leg 5; Abr 58-59; Conf 148.

${ }^{56}$ Por ejemplo, el Faraón (Det 91-95); y los egipcios (Leg 2, 34).

57 Verbi gratia, los israelitas asesinados por serpientes (Leg 2, 77-78); sobre el Éxodo (Mig 18); y sobre el maná (Mig 199-201; Agr 79-81).

${ }^{58}$ Colson, Whitaker y Marcus (trads. y eds.), Philo Judaeus, VII, 474 y 476; Triviño (trad.), Filón de Alejandría. Obras completas IV, 215.
} 
En este pasaje, Filón relata una experiencia interior profunda y muy personal. Algunos especialistas se preguntan si está refiriéndose a un rapto místico. Heininger se pregunta si se puede comparar de alguna forma esta experiencia mística con el rapto místico de Pablo (2Co 12,2-4) ${ }^{59}$. En este sentido, el pasaje clave lo constituiría Spec. 3,2; pero el léxico clave de Pablo no se encuentra en el pasaje filónico ${ }^{60}$.

No obstante, cabe señalar que la mística filónica se inscribe en la espiritualidad intelectual judía, centrada en la interpretación alegórica de las sagradas escrituras, de corte ascético, tal como el mismo Filón exalta y describe la Biblia Hebrea, discurriendo sobre los esenios, en su De vita contemplativa ${ }^{61}$. La mística filónica se entiende mejor como una propuesta de unión y acercamiento a Dios si se la encuadra en su doctrina sobre el logos. Es en esta doctrina donde Filón parece explicar su teología mística y la armonía entre teología negativa y la natural que ella implica.

\section{'O $\mu$ źøos ["el mediador"): el concepto sobre logos en Filón}

Otro aspecto importante de la teología filónica es su doctrina sobre el logos. Con ella, Filón quiere acortar la distancia entre el Dios espiritual y el mundo material, así como

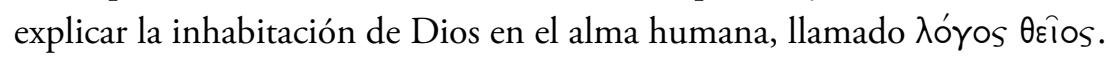

\section{Post 122}

Y también por ello Moisés presta su testimonio exhortando a combatir las doctrinas opuestas. Dice, en efecto: "La ocasión propicia los ha abandonado

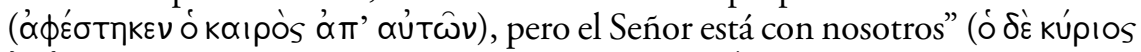

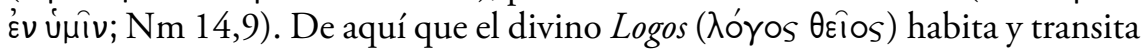
en el ámbito de aquellos por los que es honrada la vida del alma, mientras que aquellos por quienes es honrada la vida de los placeres se quedan con efímeras y ficticias oportunidades. Estos, pues, hinchados y abultados por la gordura y el deleite en creciente desarrollo, acaban por reventar. En cambio, aquellos que engordan gracias a la sabiduría, que alimenta a las almas amantes de la

\footnotetext{
${ }^{59}$ Heininger, "Paulus und Philo als Mystiker? Himmelsreisen im Vergleich (2Kor 12,2-4; SpecLeg III 1-6)", 189-204.

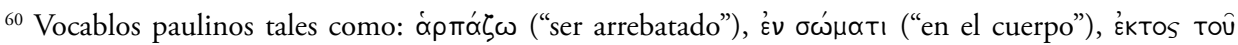

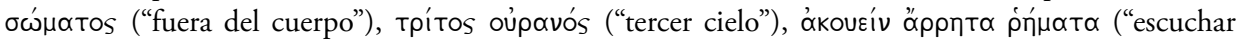
palabras sagradas"), están más cercanos al léxico de la mística apocalíptica que a la de Filón. Para una exposición general de las diferencias y convergencias entre Pablo y Filón, véase a Runia, Philo in Early Christian Literature, 66-74.

${ }^{61}$ Véase el texto en Colson, Whitaker y Marcus (trads. y eds.), Philo Judaeus IX, 112-169.
} 
virtud, adquieren firme e inconmovible fuerza, de la que es símbolo la grasa de todo animal sacrificado que se ofrece en holocausto. ${ }^{62}$

Para Filón, estos dos objetivos son muy importantes. Su tradición veterotestamentaria le ha enseñado que Dios es inmanente al mundo (doctrina creacionista) y habita en los hombres (pneumatología hebrea). Como ya se decía arriba, para Filón, Dios es inaccesible al conocimiento humano, pero él lo hace posible por medio de los poderes ${ }^{63}$. Filón piensa que en la manifestación de Dios solo se revela lo que él es, no quién es.

Filón interpreta el nombre Yahveh y su explicación (“yo soy el que soy”), como expresión de su naturaleza, no como acceso a su conocimiento: "Es mi naturaleza

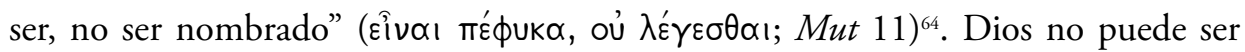
nombrado ${ }^{65}$, y por tanto no tiene cualidades o propiedades. En este sentido, el logos posibilita al hombre relacionarse con Dios. En esta función de intermediación, Filón diferencia varias posibilidades del logos, empleando diversas figuras para expresarlas.

En primer lugar, en su uso técnico del vocablo logos, Filón connota la actividad mental de Dios en el acto de la creación. Este lenguaje es tomado del mundo mental del platonismo medio, y la parábola del arquitecto lo ilustra muy bien. En Opif 16, después de afirmar que el mundo sensible, la creación de Gn 1 fue constituida a partir de un arquetipo y forma ejemplar inteligible, Filón pasa a presentar un símil con el cual hace una exégesis platónica al relato bíblico de la creación:

\section{Opif 17}

Cuando se va a fundar una ciudad para satisfacer los ambiciosos proyectos de algún rey o gobernante que, apropiándose de un poder sin límites y a la vez concibiendo brillantes ideas, busca añadir nuevo lustre a su prosperidad, algún

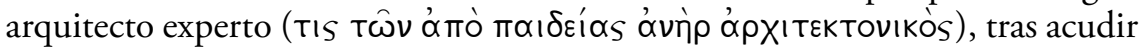
una y otra vez al lugar y observar sus ventajas de clima y posición, concibe primero en su mente el plano de casi todas las partes de la ciudad que se está

${ }^{62}$ Colson, Whitaker y Marcus (trads. y eds.), Philo Judaeus II, 398; Triviño (trad.), Filón de Alejandría. Obras completas II, 22-23. Véase también lo que escribe Filón en Som 2, 249.

${ }^{63}$ Véase Mut 11-12.

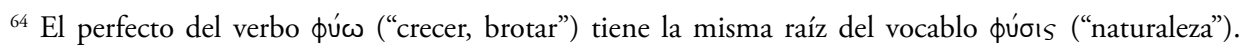
Por esto en el griego clásico se elaboraron giros lingüísticos con cierto valor filosófico. Véase los ejem-

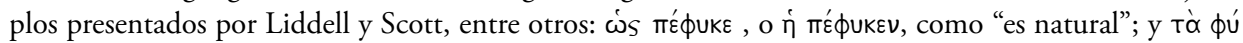
бєı пєфико́vта, como "el orden de la naturaleza". Con esta relación juega Filón en la elaboración de su teología negativa. Véase a Liddell y Scott, A Greek-English Lexicon, 1967.

${ }^{65}$ Véase Mut 7-14. 
a punto de fundar: templos, plazas, puertos, depósitos, calles, emplazamientos de murallas, ubicación de casas y demás edificios públicos. ${ }^{66}$

En Opif 18-19, Filón utiliza las imágenes cosmológicas y la filosofía platónica del

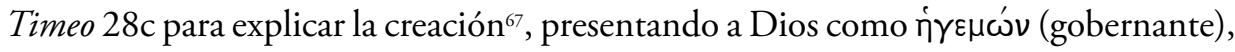

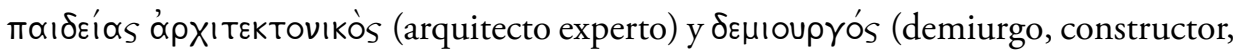
creador) que construye el cosmos, representado en el símil por medio de la imagen de $\mu \varepsilon \gamma \alpha \lambda$ ómo$_{\text {is }}$, la gran ciudad cósmica. Al continuar explicando con la cosmología y ontología platónica la creación del relato bíblico, Filón establece una correlación entre el logos divino y el arquitecto:

\section{Opif 20-22}

Así, pues, como la ciudad concebida previamente en el espíritu del arquitecto

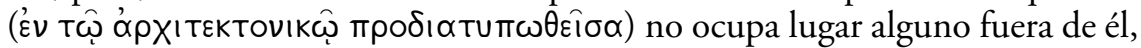

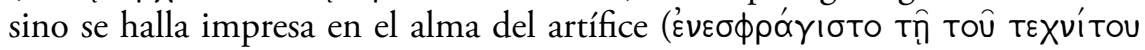
$\psi \cup \times n ̣)$, de la misma manera el mundo de las formas ejemplares no puede existir en otro lugar alguno que no sea el logos divino, que las forjó con ordenado

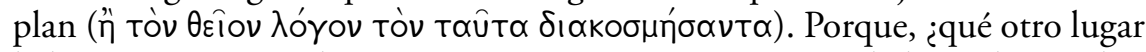
habría apto para recibir y contener en su pureza o integridad, no digo todas, pero ni siquiera una sola cualquiera de ellas, aparte de sus poderes? Y uno de

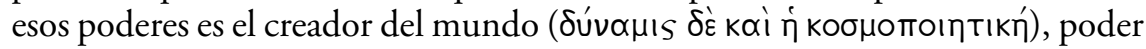
que tiene por fuente al verdadero bien. Porque entiendo yo que no andará errado quien desea averiguar la causa por la que este universo fue creado, si afirma, como, por otra parte, lo afirmó ya uno de los antiguos, que el padre y hacedor del universo es bueno, y que esa bondad hizo que no viera con malos ojos que participara de su propia naturaleza excelsa una entidad carente de por sí de toda hermosura, aunque capaz de convertirse en la totalidad de las cosas. Porque esta entidad era de por sí desordenada, sin cualidades, sin vida, sin semejanzas, llena de inconsistencia, de desarmonía y de desproporción; pero recibió una transformación, un cambio hacia las opuestas y más hermosas características, vale decir, orden, cualidad, vida, semejanza, cohesión, armonía y proporción, o sea, todo cuanto es propio de la forma ejemplar más excelente. ${ }^{68}$

El texto expone una exégesis del relato bíblico de la creación según el modelo platónico en el cual el mundo de las ideas es concebido por Dios antes del acto

\footnotetext{
${ }^{66}$ Colson, Whitaker y Marcus (trads. y eds.), Philo Judaeus, I, 14 y 16; Triviño (trad.), Filón de Alejandría. Obras completas I, 39.

${ }^{67}$ Sobre la influencia de este pasaje platónico en la obra de Filón, así como de otros autores judíos y cristianos de la antigüedad, véase a Runia, Philo of Alexandria and the Timaeus of Plato, Vol. 1. Para una interpretación de todo el pasaje, véase el comentario de Runia, Philo of Alexandria. On the Creation of the Cosmos According to Moses, 141-142.

${ }^{68}$ Colson, Whitaker y Marcus (trads. y eds.), Philo Judaeus I, 16 y 18; Triviño (trad.), Filón de Alejandría. Obras completas I, 39-40.
} 
creativo del mundo sensible (Opif 24-25) ${ }^{6}$. Aquí el logos es entendido como uno de los

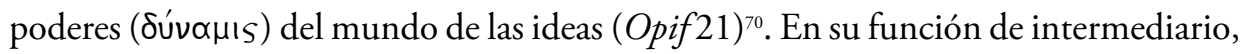
el logos es prefigurado en el sumo sacerdote y en Aarón. Además de pasajes como Som 1,215 y Fug 106-112

¿Observas cómo ni siquiera el sumo sacerdote, el logos, aunque posee poder para entregarse a la tranquila meditación de las sagradas doctrinas, ha alcanzado licencia para acercarse a ellas en todo tiempo, y apenas le es dado hacerlo una vez al ańo? Es que el logos en forma de palabra no es constante pues esta es doble; en cambio, la contemplación del que es a través del alma solamente, sin mediación de palabra, es totalmente segura por cuanto se basa en la indivisible unidad..$^{72}$

En segundo lugar y siguiendo el uso de las imágenes veterotestamentarias, Filón habla de la intermediación histórica del logos en favor de Israel; es presentado como el maná (Heres 191) y como la piedra del desierto (Som 1, 241-242). En estos ejemplos se observa mucha relación con las prefiguraciones que el Nuevo Testamento adjudica a Jesús, especialmente en Pablo, Juan y la Carta a los Hebreos. ${ }^{73}$

El significado del logos en Filón es muy complejo; incluye el concepto e imágenes bíblicas de "palabra", seres celestiales, la Ley mosáica, así como conceptos del platonismo medio. En algunas citas, Filón usa el concepto sapiencial hebreo de

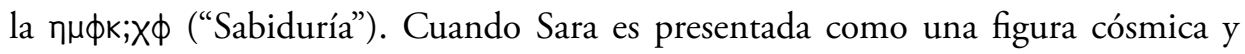

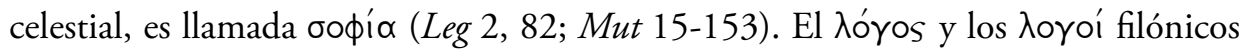
pueden ser concebidos como figuras celestiales, ángeles o arcángeles. Incluso el logos es considerado como un segundo dios:

Som 1, 230

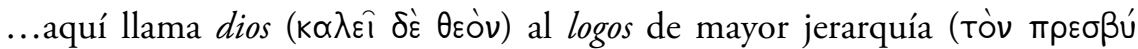
Tatov), no porque le guíe la superstición en la asignación de los nombres, sino con una sola intención, la de ajustar la narración a los hechos. así, en

\footnotetext{
${ }^{69}$ Véase el comentario de van Winden, "The World of Ideas in Philo of Alexandria: An Interpretation of the Opificio Mundi 24-25”, 209-217.

${ }^{70}$ Sobre la relación de los dos poderes y la doctrina del logos, Runia, Philo of Alexandria. On the Creation of the Cosmos According to Moses, 144, explica sucintamente: “... as in the case of the divine Logos, Philo appears to assign both a transcendent and an immanent role to the powers. In our text the former is dominant, but the latter too must be assumed".

${ }^{71}$ Una interpretación similar es ofrecida por Williamson, Jews in the Hellenistic World. Philo, 136-143, quien entiende al sumo sacerdote como el Logos divino, en cuanto intermediario.

${ }^{72}$ Colson, Whitaker y Marcus (trads. y eds.), Philo Judaeus II, 470; Triviño (trad.), Filón de Alejandria. Obras completas II, 41-42.

${ }^{73}$ Sobre esto, véase a Runia, Philo in Early Christian Literature, 63-83.
} 
otro pasaje al inquirir si existe algún nombre aplicable al que es, claramente reconoció que no hay ninguno apropiado para él, y que cualquiera que se le aplicare será por licencia de lenguaje; porque la naturaleza del que es no es expresable, solamente es. ${ }^{74}$

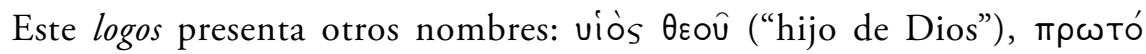

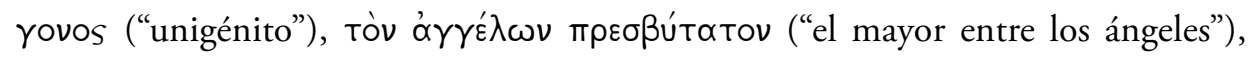

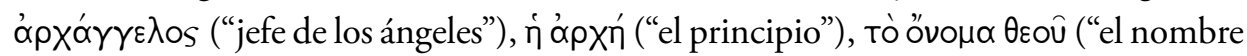

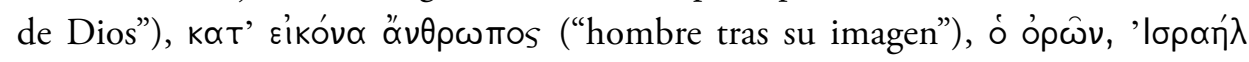
("aquel que ve: Israel”) 75 . El logos filónico, moldeado según la figura del demiurgo, por un lado, y de la $\eta \mu \phi k ; \chi \phi$ hebrea, por otro, es el mediador entre los hombres y Dios $^{76}$. Esta compleja construcción conceptual la ilustra el siguiente pasaje.

Heres 205-206

El Padre que creó el universo concedió al Arcángel, al logos venerabilísimo, un privilegio extraordinario: estar en medio para separar lo creado del Creador. Él es el intercesor del mortal, siempre angustiado, ante el eterno, y embajador del guía ante el súbdito. Él está exultante con este privilegio y, lleno de orgullo, lo describe diciendo: "Y yo estaba en medio del Señor y de vosotros" (Dt 5,5), y

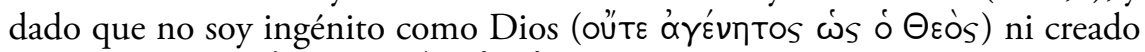

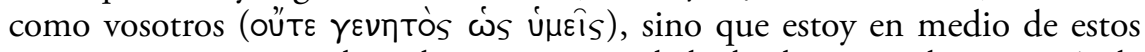
extremos, soy garante de ambos: ante quien la ha hecho nacer doy garantía de que la criatura no se desbocará por completo nunca ni se rebelará escogiendo el desorden en lugar del orden; ante el nacido doy la esperanza de que el benigno Dios nunca se desentenderá de su propia obra. Yo soy enviado a proclamar la paz a la creación de parte de Dios, que ha decidido acabar con las guerras y es siempre el guardián de la paz. ${ }^{77}$

Este punto intermedio, indeterminado de la esencia del logos filónico, que no es divino ni humano, lo acercará y alejará, al mismo tiempo, del concepto del logos aplicado a Jesús, pues para los escritores neotestamentarios, el logos es tanto divino como humano $^{78}$.

\footnotetext{
${ }^{74}$ Colson, Whitaker y Marcus (trads. y eds.), Philo Judaeus V, 418; Triviño (trad.), Filón de Alejandría. Obras completas III, 176.

${ }^{75}$ Sobre estos nombres, véase Conf 146.

${ }^{76}$ Véase a Williamson, Jews in the Hellenistic World. Philo, 119-120.

${ }^{77}$ Colson, Whitaker y Marcus (trads. y eds.), Philo Judaeus IV, 384 y 386; Martín (dir.), Filón de Alejandría. Obras completas III, 195.

${ }^{78}$ Por ejemplo, en pasajes neotestamentarios como Jn 1,1.14; Hb 1,2-4; 4,15; 5,5-6; y Flp 2,6.
} 


\section{Conclusiones}

Al leer la obra filónica no solo se encuentra a un judío alejandrino que hace lectura de su tradición bíblica a la luz de la paideia griega, o a un traductor de la tradición judía a categorías filosóficas griegas. A Filón no se le puede entender simplemente como un apologeta del valor cultural del judaísmo presentado como una venerable tradición filosófica. Mejor es verle como un exponente del encuentro entre helenismo y judaísmo, y un notable exponente del platonismo medio.

En este sentido se le puede ver como un traductor, pero no uno mecánico, como se anotó arriba, sino dinámico; uno que, mejor que transliterar al griego su cultura hebrea, ve, entiende, ama y habla de su tradición judía desde el prisma que el paradigma helenista le ofrecía. Filón es tanto un exégeta como un teólogo judío del paradigma helenístico.

Como exégeta comenta la Torah. Su método de exégesis no es el midrash o el pesher, como ocurre en Palestina (por ejemplo, en Qumrán), sino la alegoresis, propia de la tradición teológica de la enseñanza moral estoica ${ }^{79}$. Así como en las escuelas griegas de filosofía se eleva al nivel de typus a las figuras de los héroes y dioses, Filón presenta a los patriarcas (Abraham, José, etc.) y a Moisés.

$\mathrm{Al}$ alejandrino no le interesa tanto indicar una comparación entre la Torah y $\mathrm{La}$ Ilíada; mejor pretende ver, entender y hablar de sus figuras patriarcales (héroes) desde el prisma del paradigma cultural helenístico. Como exégeta de su tradición escrita, Filón se comporta como un judío que no puede entender su propia tradición desde ninguna otra posición diferente a la determinada por las coordenadas temporales y culturales. Filón interpreta su tradición como un judío helenizado.

Como teólogo, Filón propone un notable sistema, desechado por la naciente corriente farisaico-rabínica que luego desarrollaría el sistema teológico rabínico clásico (70-640 d. C.), con la Mishna y el Talmud, pero que vale la pena recuperar ${ }^{80}$. En el presente texto solo se han expuesto dos líneas de la amplísima teología filónica. La primera, más cercana a la definición platónica de "teología”, expone la teología mística como centro de su sistema teológico.

Llama la atención la unión de los problemas propios de la epistemología del platonismo medio, la teología natural y la negativa en el misticismo de Filón. La

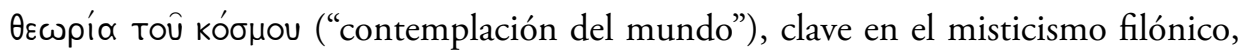
se presenta en el marco de una argumentación sobre la posibilidad de conocer a Dios

\footnotetext{
${ }^{79}$ Así lo señalan Borgen, Philo of Alexandria: An Exegete for His Time; y Runia, Exegesis and Philosophy, 209-217.

${ }^{80}$ Así mismo opina Chilton, "Judaism and Christianity in the Formative Age", 128.
} 
por medio de su teología del logos. La teología de Filón es un conocimiento de Dios a partir del dato bíblico, que expresa la imposibilidad de acceder por los sentidos (teología negativa), pero sí experimentar con el alma. En su teología del logos desarrolla toda una teoría de intermediación que permite explicar como el Dios absolutamente otro e inefable puede tener un contacto histórico con el hombre (por medio de los ángeles, y de figuras heroicas como Moisés, Aarón, etc.) por un lado y, por otro, cómo puede darse el mal.

Se presentaron otros sistemas teológicos judíos que desarrollan un monoteísmo modificado y una amplía demonología a partir de una exégesis de la Torah, como es el caso del así llamado judaísmo henóquico. Filón presenta una versión paralela y diferente a aquella de la demonología henóquica. No obstante, su solución se enfrenta con las concepciones rigoristas de la doctrina monoteísta rabínica posterior.

La segunda línea teológica trata el problema de la teodicea. La tradición bíblica en sí misma puede ser entendida como una teodicea narrativa ${ }^{81}$, pero el monoteísmo radical agudiza el problema al presentar a Dios como causa única de lo bueno y lo malo. Desde la introducción de los sistemas demonológicos y angelológicos persas en el judaísmo, la doctrina monoteísta comienza a sufrir un cambio, abriendo paso a un monoteísmo modificado. Filón soluciona el problema de la teodicea del judaísmo helenista por medio de estos sistemas angelológicos y demonológicos.

\section{Referencias}

Aland, Kurt (ed.) Vollständige Konkordanz zum Griechischen zum Neuen Testament. New York/Berlin: Walter De Gruyter, 1978.

Alekniené, T. "L'extase” mystique dans la tradition platonicienne: Philon d'Alexandrie et Plotin". Studia Philonica Annual 22 (2010): 53-82.

Anderson (Jr), R. Dean. “allègoria”. En Glossary of Greek Rhetorical Terms, editado por R. Dean Anderson, 14-16. Leuven: Peeters, 2000.

Aranda Pérez, Gonzalo y otros. Literatura judía intertestamentaria. Estella (Navarra): Verbo Divino, 1996.

\footnotetext{
${ }^{81}$ En su artículo, Kaiser -apoyado en la tesis de Metz, quien considera la teodicea como tema clave de la teología bíblica- entiende la narración bíblica como teodicea en cuanto es una narración que crea un sentido temporal ("die biblische Gottesrede als temporale Rede") para la vida del lector-creyente (Kaiser, "Theodizee als biblisch erzählte Geschichte”, 115-142, especialmente 117).
} 
Beumer, J. "El método teológico". En Historia de los dogmas. Tomo 1. Cuaderno 6, editado por Michael Schmaus, Alois Grillmier, Leo Scheffczy, 1-16. Madrid: Biblioteca de Autores Cristianos, 1977.

Birnbaum, Ellen. The Place of Judaism in Philo's Thought. Atlanta (GA): Scholars Press, 1996.

Borgen, Peder. "Philo of Alexandria". En Anchor Bible Dictionary, editado por David N. Freedman V, 333-342. New York (NY): Doubleday, 1992. . Philo of Alexandria: An Exegete for His Time. Leiden-Boston: Brill. 1997.

Bousset, Wilhelm. Jüdisch -christlicher Schulbetrieb in Alexandria und Rom. Göttingen: Vandenhoeck \& Ruprecht, 1915.

Brewer, David I. Techniques and Assumptions in Jewish Exegesis Before 70 CE. Tübingen: Mohr Siebeck, 1992.

Cadiou, René. Philon D'Alexandrie: La Migration d Abraham. Paris: Du Cerf, 1957.

Calabi, Francesca. God's Acting, Man's Acting. Leiden-Boston: Brill, 2008. . (ed.) Italian Studies on Philo of Alexandria. Boston-Leiden: Brill, 2003.

Chilton, Bruce D. "Judaism and Christianity in the Formative Age". En The Blackwell Companion to Judaism, editado por Jacob Neusner y A. J. Avery-Peck, 112-130. Oxford (UK: Blackwell Publishing, 2003.

Cohen, Naomi G. Philo's Scriptures Citations from Prophets and Writtings. LeidenBoston: Brill, 2007.

Colson, F. H.; G. H. Whitaker; y Ralph Marcus (trads. y eds.). Philo Judaeus. With an English Translation. 10 vols. Cambridge (MA): Harvard University Press, 1981-1991.

Culpepper, R. Alan. The Johannine School. Missoula (MT): Scholars Press, 1975.

Davies, William D. y Louis Finkelstein (eds.) The Cambridge History of Judaism. 2: The Hellenistic Age. Cambridge (UK): Cambridge University Press, 1989.

Díez Macho, Alejandro. Apócrifos del Antiguo Testamento. Tomo 1: Introducción general. Madrid: Cristiandad, 1984.

Dillon, John. The Golden Chain: Studies in the Development of Platonism and Christianity. Aldershot-Brookfield (VT): Variorum, 1990.

Gilson, Étienne. Las constantes filosóficas del ser. Pamplona: Eunsa, 2005. 
Grabbe, Lester L. A History of the Jews and Judaism in the Second Temple Period. Vol. 2: The Early Hellenistic Period, 335-175 BCE. New York (NY): T \& T Clark, 2008.

- (ed.) Did Moses Speak Attic? Jewish Historiography and Scripture in the Hellenistic Period. Sheffield: JSOT Press, 2001.

Goodenough, Erwin R. An Introduction to Philo Judaus. New Haven (CN): Yale University Press, 1940.

. "New Light on Hellenistic Judaism". Journal of Bible and Religion 5 (1937): 18-28.

Goodhart, Howard L. y Erwin R. Goodenough. "A General Bibliography of Philo Judaeus". En The Politics of Philo Judaeus: Practice and Theory, editado por E. R. Goodenough, 125-321. New Haven (CN): Yale University Press, 1938.

Heininger, Bernhard."Paulus und Philo als Mystiker? Himmelsreisen im Vergleich (2Kor 12,2-4; SpecLeg III 1-6)”. En Philo und das Neuen Testament, editado por Rolad Deines y Karl-W. Niebuhr, 189-204. Tübingen: Mohr Siebeck, 2004.

Hengel, Martin. Giudaismo ed ellenismo. Brescia: Paideia, 2001. . The Hellenization of Judaea in the First Century after Christ. London: SCM Press, 1984.

Holladay, Carl R. Fragments from Hellenistic Jewish. Vol. 3: Aristobulus. Atlanta (GA): Scholars Press, 1995.

Jonas, Hans. Gnosis und spätantiker Geist. Bd. 1: Die mythologischer Gnosis (4. ${ }^{a}$ ed.). Göttingen: Vandenhoeck \& Ruprecht, 1998.

Kaiser, Gerhard. “Theodizee als biblisch erzählte Geschichte”. Zeitschrift für Theologie und Kirche 102 (2005): 115-142.

Klein, F.-N. Die Lichtterminologie bei Philon von Alexandrien und in den hermetischen Schriften. Leiden: Brill, 1962.

Krämer, Hans J. Platonismus und hellenistische Philosophie. Berlin-New York: Walter de Gruyter, 1971.

Liddell, Henry G. y Robert Scott. A Greek-English Lexicon. Revised and Augmented Throughout by Sir Henry Stuart Jones, with the Assistance of Roderick McKenzie. With a Revised Supplement. Oxford: Claredon Press, 1996. 
Loveday, Alexander. "Schools, Hellenistic”. En Anchor Bible Dictionary, editado por David N. Freedman V, 1005-1111. New York (NY): Doubleday, 1992.

Mackie, S. D. "Seeing God in Philo of Alexandria: the Logos, the Powers, or the Existent One?”. Studia Philonica Annual 21 (2009): 25-47.

Manning, J. G. Land and Power in Ptolemaic Egypt. Cambridge (UK): Cambridge University Press, 2009.

Martín, José Pablo (dir.). Filón de Alejandría. Obras completas. Vol. I. Madrid: Trotta, 2009. . Filón de Alejandría. Obras completas. Vol. II. Madrid: Trotta, 2010. . Filón de Alejandría. Obras completas. Vol. III. Madrid: Trotta, 2012. . Filón de Alejandría. Obras completas. Vol. IV. Madrid: Trotta, 2016.

Matusova, E. "Allegorical Interpretation of the Pentateuch in Alexandria: Inscribing Aristobulus and Philo in a Wider Literary Context". Studia Philonica Annual 22 (2010): 1-52.

Moreau, J. "A Noocentric Exegesis: The Function of Allegory in Philo of Alexandria and Its Hermeneutical Implications". Studia Philonica Annual 29 (2017): 61-80.

Moulton, James H. The Vocabulary of the Greek Testament Illustrated from the Papyri and Other Non-Literary Sources. London: Hodder and Stoughton, 1914.

Muraoka, Takamitsu. A Greek English-Lexicon of the Septuagint. Louvain-Paris-Walpole: Peeters, 2009.

Nairne, Alexander. The Alexandrine Gospel: Sirach, Wisdom, Philo, the Epistle to the Hebrews. London/New York: Longmans, Green \& Co., 1917.

Niehoff, Maren R. Jewish Exegesis and Homeric Scholarship in Alexandria. Cambridge (UK): Cambridge University Press, 2011.

Nikiprowetzky, V. Le commentaire de lÉcriture chez Philon d Alexandrie. Leiden: Brill, 1977.

Pearson, Birger A. "Christians and Jews in First-Century Alexandria". Harvard Theological Review 79 (1986): 206-216.

Praechter, Karl. Friedrich Ueberwegs. Grundrifs der Geschichte der Philosophie. Erster Teil: Das Altertum. Berlin: Ernst Siegfried Mittler und Sohn, 1920. 
Reventlow, Hening G. History of Biblical Interpretation. Volume 1: From the Old Testament to Origen. Atlanta (GA): Society of Biblical Literature, 2009.

Runia, David T. Exegesis and Philosophy. Aldershot (VT): Variorum, 1990. . Philo in Early Christian Literature. Minneapolis (MN): Fortress Press, 1999. . Philo of Alexandria and the Timaeus of Plato, Vol. 1. Amsterdam: Vrije Universiteit Boekhandel, 1983.

. Philo of Alexandria. On the Creation of the Cosmos According to Moses. LeidenBoston: Köln-Brill, 2001.

Runia, David T., y otros. "Philo of Alexandria: An Annotated Bibliography (2014)". Studia Philonica Annual 29 (2017): 185-228.

Runia, David T. y Roberto Radice. Philo of Alexandria: An Annotated Bibliography. 1937-1986. Leiden-Boston: Brill, 1988.

. Philo of Alexandria: An Annotated Bibliography. 1987-1996. Leiden-Boston:Köln- Brill, 2001.

. Philo of Alexandria: An Annotated Bibliography. 1997-2006. Leiden-Boston: Brill, 2012.

Saudelli, L. "Loi de Moïse et philosophie grecque: le judaïsme alexandrin". En Alexandrie la divine, editado por Charles Méla y Fréderic Möri, 726-731. Neuchâtel: La Baconnière, 2014.

Scholem, Gershom. Jewish Gnosticism, Merkabah Mysticism, and Talmudic Tradition. New York (NY): The Jewish Theological Seminary of America, 1965.

Segal, Alan F. Two Powers in Heaven: Early Rabbinic Reports about Christianity and Gnosticism. Leiden-Boston: Brill, 2002.

Sterling, G. "'The School of Sacred Laws': The Social Setting of Philo's Treatises". Vigilia Christiana 53 (1999): 148-164.

Stone, Michael E. Jewish Writings of the Second Temple Period. Philadelphia (PA): Fortress Press, 1984.

Stuckenbruck, Loren T. The Book of Giants from Qumran. Tübingen: Mohr Siebeck, 1997.

Stroumsa, Gedaliahu A.G. Another Seed: Studies in Gnostic Mythologies. Leiden: Brill, 1984. 
Tarn, William W. Alexander the Great. Vol. 2: Sources and Studies. Cambridge (UK): Cambridge University Press, 1950.

Triviño, José M. (trad., notas e introducción). Filón de Alejandría. Obras completas. Vol. 1. Buenos Aires: Acevedo Cultural Editores, 1976. . Filón de Alejandría. Obras completas. Vol. 2. Buenos Aires: Acevedo Cultural Editores, 197.

. Filón de Alejandría. Obras completas. Vol. 3. Buenos Aires: Acevedo Cultural Editores, 1976.

. Filón de Alejandría. Obras completas. Vol. 4. Buenos Aires: Acevedo Cultural Editores, 1976.

Van Winden, J. C. M. "The World of Ideas in Philo of Alexandria: An Interpretation of the Opificio Mundi 24-25”. Vigilia Christiana 37 (1983): 209-217.

Vílchez Lindez, J. Sabiduría. Estella (Navarra): Verbo Divino, 1990.

Watts, E. J. City and School in Late Antique Athens and Alexandria. Los Angeles (CA): California University Press, 2006.

Wilckens, Ulrich. La Carta a los Romanos. Tomo 1: Rom 1-5.3 ed. Salamanca, Sígueme, 2006.

Williamson, Ronald. Jews in the Hellenistic World. Philo. Cambridge (UK): Cambridge University Press, 1989.

Winston, David. Logos and Mystical Theology in Philo of Alexandria. Cincinnati (OH): Hebrew Union College Press, 1985. 